ISBN 978-93-84468-83-5

International Conference on Studies in Arts, Law and Education

(ICALE-2016)

Singapore Dec. 5-6, 2016

\title{
Factors of Marketing Affecting the Selection of Private Hospital in Thailand
}

\author{
Dr. Chinnaso Visitnitikija, and Lu Shi \\ chinnaso12@gmail.com \\ Kasembundit University,Bangkok
}

\begin{abstract}
The purpose of the study is to determine the process of decision making and factors affecting foreign patients on choosing private hospital in Thailand. The samplings were 385 foreign patients who chose private hospital in Thailand by using a check list and rating scale as a questionnaire. Statistic applications for data analysis was percentage, mean, standard deviation, one-way Anova, and regression analysis.

Findings from the study indicated that most of respondents were female, age 31-40 years old, bachelor degree or higher graduated, self-employed, average monthly income 45,000-60,000 baht, using a type of group medical insurance benefit program as payment, and selection from self-decision. The overall picture of the opinions of marketing mix factors persuading foreign patients on choosing private hospital in Thailand were in high level for the reasons as following aspects: Medical services aspect, emphasize on professional treatment from personnel, give advice about medication, and follow up on the treatment for all patients. Prices aspect, emphasize on prices appropriate and compatible to other hospitals with quality medical services, and with some special promotion prices package. Location aspect, emphasize of travel convenient, available parking spaces, within the vicinity such as neighborhood, offices, and department stores. Marketing promotion, special prices package, installment plan with credit cards, speedy service, appropriate of medical care period, and bills payment with reasonable time. Personnel aspect, professional medical personnel with courtesy and have bedside manners. The test of hypothesis results revealed that marketing mix consisting of medical treatment services, patient follow up, appropriate treatment time, and paying bill with reasonable time correlated to foreigner patients' behavior on choosing private hospital for medical services at significant level 0.05.

Recommendations from the results of the study were that administrative officers should focus on marketing mix of services, professional doctors and nurses, doctors' specialist in specific field, and reasonable with appropriate prices. As for marketing promotion should offer special package prices, for example, special prices package of yearly medical checkup. Offers one stop services to reduce hospital time. Yearly training service personnel for ethical and morality standards in order to provide healthcare professionals with high standard of medical services.
\end{abstract}

Keywords: Marketing, Hospital, Thailand

\section{Introduction}

The circumstances of rapidly changing of world environmental, physical, economic, and social which result in the demand for health services increased from the main reasons of the increase of elderly population according to studies of Institute for population and social research, Mahidol University, 2010, and the number of diseases that are also increased. From the research analysis study, patterns of emerging infectious diseases of 335 cases events during the year 1940-2004 B.E. revealed that the emerging disease has happened since 1980 decade onwards, all of this emerging disease 60.3 percent which the disease 
spread from animals to human contact, diseases are often caused by wild animals, such as SARS (severe acute respiratory syndrome) Bird flu, Ebola hemorrhagic, etc. The emerging disease 54.3 percent, caused by a bacterial infection. The outlook of these disease has an impact on society, economy, and environment of ecological factors very seriously. It also revealed that areas in the lower latitude levels have a higher risk of emerging disease that is caused by a wild life animals or insects. The research study report has concluded that the distribution of resources around the world in response to emerging diseases have not been covered, especially academic potential and disease surveillance in countries with the least risk to the emerging diseases has strengthened more than country with high risk. The professional nursing as a profession with labor demand and high employment rate. The rate of total employments in year 2014 was up to 2,729,647 persons, and needs of professional nursing jobs representing the 122,922 positions, and actually hired only 103,804 positions in each month. The result of scarcity in a career was very high rate. The average growth in annually 2010-2014 is a relatively low of 5 percent only, average hourly wages rate of $\$ 32.51$ or 1,069 baht. Make a nursing career shortage at the top in the world. Therefore, patient groups worldwide, finding an effective health services throughout the world to treat old ages with poor health from the disease which emerging each year.

Healthcare services business in Thailand, have rate of labor increased the most in the past 10 years when compare to other industries of the labor market with continuous revenue, such as the tourist industry and the food industry, etc., regarded as the key to the economic development of Thailand's medical treatment services. The incomes from the medical services of foreigners continued, and each year foreigners coming for medical treatment services more than 1 million people, and likely increasing every year.

\section{Purpose of the Study}

1. To determine the decision making process of foreign patients on choosing private hospital in Thailand.

2. To determine factors affecting foreign patients on choosing private hospital in Thailand

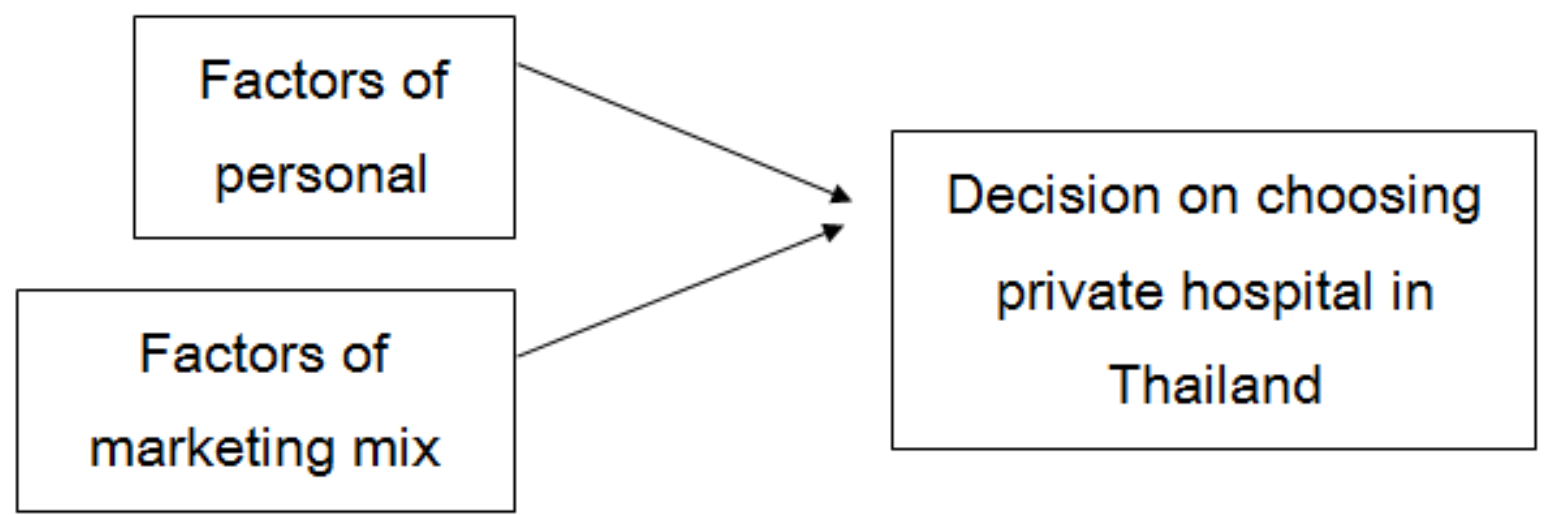

\section{Research Methodology}

\subsection{Sample Selection}

The purpose of the study is to determine the process of decision making and factors affecting foreign patients on choosing private hospital in Thailand. The samplings were 385 foreign patients who chose private hospital in Thailand. 


\section{Data Collection Procedure}

The questionnaires were distributed to the sampling of 385 foreign patients who chose private hospital in Thailand. A total of 385 usable questionnaires were returned back to the researcher, yielding a 100 percent response rate and no missing data.

The overall picture of the opinions of marketing mix factors

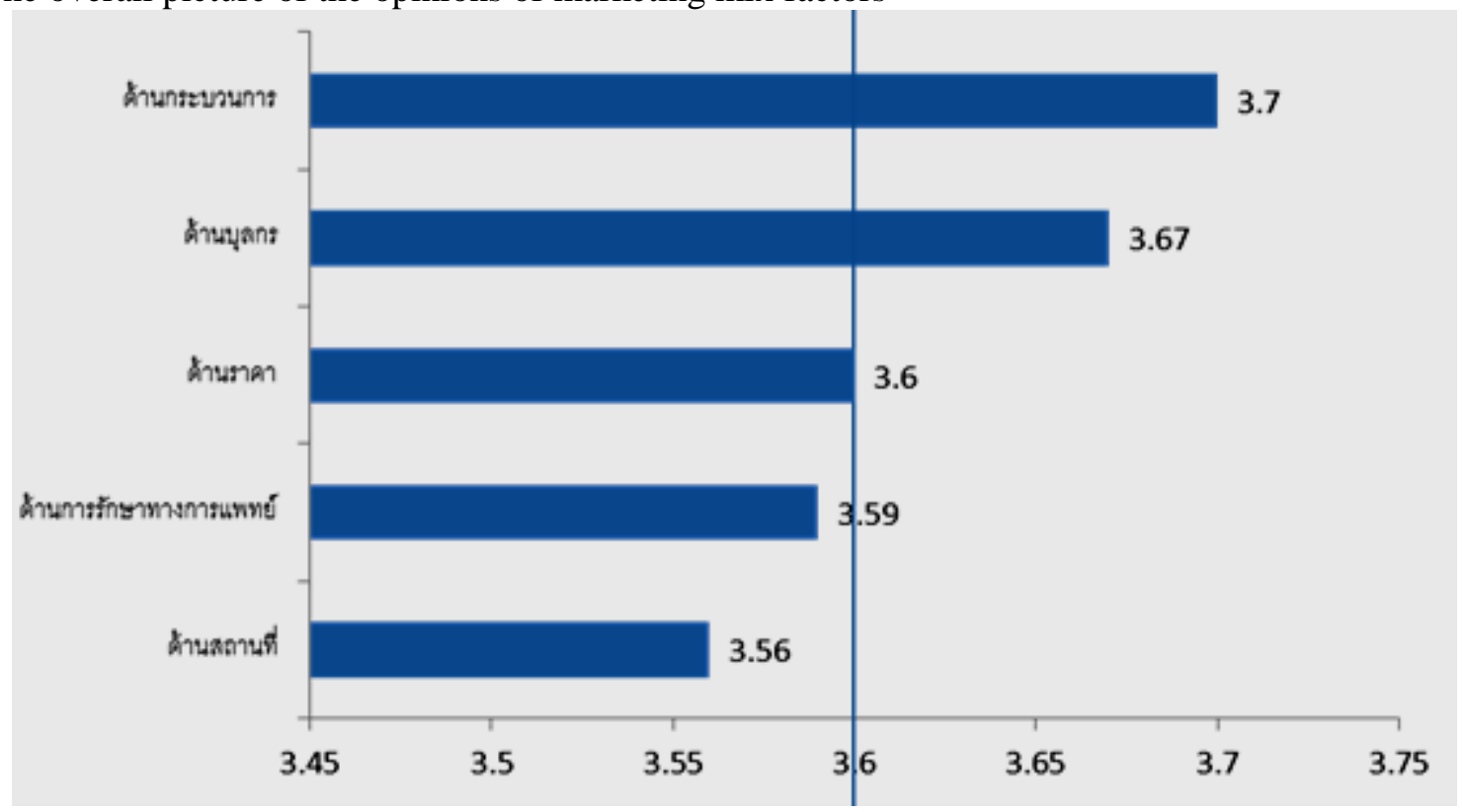

Fig. 1 The overall picture of the opinions of marketing mix factors

From figure 1: the overall picture of the opinions of marketing mix factors were in high level $(\bar{x}=3.60)$ consisting of the process aspect $(\bar{x}=3.70)$ and human resources aspect $(\bar{x}=3.67)$. The overall picture of the opinions of marketing mix factors were in medium level consisting of prices aspect $(\bar{x}=3.60)$. The overall picture of the opinions of marketing mix factors were in low level $(\bar{x}=3.61)$ consisting of medical treatment aspect $(\bar{x}=3.59)$, and place aspect $(\bar{x}=3.56)$, respectively.

The test of hypothesis to find the answer, if and how the dependent variables influence by independent variables, any independent variables can predict the dependent variables outcome by using statistical multiple regression analysis. The details of the multiple regression analysis of the variable element of marketing mix factors has resulted in the selected medical treatment at private hospitals in Thailand.

From the table below, the results from hypothesis testing 2 with value of regression at significant level 0.05 revealed that factors of marketing mix correlated to decision making of foreign patients on choosing private hospital in Thailand at significant level $=0.049,0.011$, and 0.042 , respectively. Denied hypothesis $\mathrm{HO}$ meaning factors of marketing mix, such as medical treatment follow up with the patients, appropriate period of hospital stay, and speedy services on paying medical services correlated to decision making of foreign patients on choosing private hospital in Thailand at significant level 0.05.

Recommendations from the study results were that administrative officers of the hospital should emphasize on marketing mix and adapt marketing strategy in various area as follows: medical and clinical services, competent doctors, nurses, and other hospital personnel, the specialist doctors in the different field of treatments, training hospital personnel from the company that certified by ISO, and offer the best quality services to foreign patients when they are here in private hospital in Thailand. 


\begin{tabular}{|c|c|c|c|c|c|}
\hline & \multicolumn{2}{|c|}{$\begin{array}{l}\text { Unstandardized } \\
\text { Coefficients }\end{array}$} & \multirow{2}{*}{$\begin{array}{c}\begin{array}{c}\text { Standardized } \\
\text { Coefficients }\end{array} \\
\text { Beta }\end{array}$} & \multirow{2}{*}{$\mathrm{T}$} & \multirow{2}{*}{ Sig. } \\
\hline & $\mathrm{B}$ & $\begin{array}{l}\text { Std. } \\
\text { error }\end{array}$ & & & \\
\hline (Constant) & 1.140 & .421 & & 2.709 & .008 \\
\hline \multicolumn{6}{|c|}{ Medical treatment services aspect } \\
\hline Good services from medical personnel & .040 & .101 & .048 & .402 & .689 \\
\hline Competent doctors personnel & .052 & .102 & .066 & .515 & .608 \\
\hline Advice on medical procedure & .001 & .092 & .001 & .007 & .995 \\
\hline Advice on medicine & .073 & .081 & .099 & .895 & .373 \\
\hline Follow up on medical treatment with patients & .183 & .091 & .230 & 2.001 & .049 \\
\hline \multicolumn{6}{|c|}{ Prices aspect } \\
\hline Medical bills appropriate to medical services & .054 & .099 & .070 & .547 & .586 \\
\hline Medical bills appropriate to medical services quality & .038 & .101 & .056 & .380 & .705 \\
\hline Medical bills are cheaper than other hospital & .041 & .101 & .046 & .406 & .686 \\
\hline Discount bills when using promotion package & -.049 & .099 & -.061 & -.488 & .627 \\
\hline Special discount prices & .184 & .103 & .224 & 1.788 & .078 \\
\hline \multicolumn{6}{|c|}{ Place aspect } \\
\hline Travel convenient & -.053 & .107 & -.062 & -.495 & .622 \\
\hline Available parking spaces & .118 & .110 & .146 & 1.073 & .287 \\
\hline Hospital within vicinity & .149 & .103 & .174 & 1.443 & .153 \\
\hline Hospital within office distant & -.131 & .110 & -.157 & -1.192 & .237 \\
\hline Hospital within shopping malls distant & .133 & .106 & .154 & 1.254 & .214 \\
\hline \multicolumn{6}{|c|}{ Marketing promotion } \\
\hline Special prices for medical treatment program & -.130 & .096 & -.162 & -1.354 & .180 \\
\hline Installment plan when using credit cards & -.113 & .104 & -.155 & -1.090 & .279 \\
\hline Gift voucher & .098 & .093 & .138 & 1.057 & .294 \\
\hline \multicolumn{6}{|c|}{ Services procedures } \\
\hline Fast services procedures & .095 & .098 & .130 & .970 & .335 \\
\hline Appropriate period of medical treatment & -.287 & .110 & -.346 & -2.614 & .011 \\
\hline Conveniently to pay medical bills & .197 & .095 & .242 & 2.072 & .042 \\
\hline \multicolumn{6}{|c|}{ Hospital service and personnel } \\
\hline $\begin{array}{l}\text { From medical treatment and personnel services } \\
\text { persuade patients to choose private hospital }\end{array}$ & .066 & .113 & .080 & .584 & .561 \\
\hline $\begin{array}{l}\text { Medical personnel affecting patient decision to choose } \\
\text { private hospital }\end{array}$ & -.076 & .104 & -.100 & -.732 & .466 \\
\hline $\begin{array}{l}\text { Services reliability factor affecting patients decision on } \\
\text { choosing private hospital }\end{array}$ & -.166 & .095 & -.208 & -1.740 & .086 \\
\hline $\begin{array}{l}\text { Understanding and sympathizing of patients affecting } \\
\text { decision on choosing private hospital }\end{array}$ & -.003 & .108 & -.004 & -.029 & .977 \\
\hline
\end{tabular}

\section{References}

[1] Kulaya Vanichbuncha. (2549 B.E.). Statistics for the research. $2^{\text {nd }}$ edition. Bangkok: Chulalongkorn University.

[2] Kulaya Vanichbuncha. (2551 B.E.). Data analysis of variables. $3^{\text {rd }}$ edition. Bangkok. Chulalongkorn University.

[3] Kamjira Poomgalong. (2553 B.E.). Outpatient satisfaction of service quality of Pathumtani Hospital. Independent Study. Rajamangala Institute of Technology, Tanyaburi.

[4] Chantana Raknark. (2554 B.E.). Factors of marketing affecting patients' decision on using private Large size of hospital services. Bangkok. Independent Study. Panyapivat Institute. 
[5] Chanida Kruajaturas. (2553 B.E.). Factors affecting working age consumer decision on buying medical insurance in Bangkok region. Bangkok. Independent Study. NIDA.

[6] Chanida Pavanaporn. (2555 B.E.). Factors affecting consumer behavior on selecting services from Krung Thai Bank, Tivanont branch. Independent Study. Siam University.

[7] Chaivat Showcharoensuk. (2556 $\quad$ B.E.). Private hospital business. Searched from http://www.lhbank.co.th/content/upload/documents/-85881849995420837808. 